\title{
Study on Problems and Countermeasures of Labor Supervision in China
}

\author{
Jiaqi Zhang \\ North China Electric Power University, Beijing, 102206,China \\ Email:18811187855@163.com
}

Key words: Labor supervision, Legislation, Organizational structure system, Law enforcement mechanism

\begin{abstract}
Labor supervision is a kind of measure that the state uses administrative power to intervene and supervise labor relations. It is of great significance to prevent the labor disputes and maintain the legitimate rights and interests of employees. It also means a lot for building harmonious and stable labor relations. As for the problems of labor supervision system in the process of legislating, organizational structure system and law enforcement, some countermeasures are needed, such as perfecting supervision legislation, perfecting organizational structure system and law enforcement system, establishing monitoring and early warning system to explore the key to perfect the labor supervision system.
\end{abstract}

Labor supervision refers to the activities that the organizations with statutory supervision power supervise and examine the implementation of labor laws and regulations by the employers and labor service entities and deal with the illegal acts found [1], which is an important way to achieve the relief of employees' rights.

Exercising a series of powers conferred by the law, the labor supervision department punishes and adjusts the illegal acts of the employing units in a timely manner, which is conducive to the coordination of the labor relations and labor dispute prevention. Maintaining the legitimate rights and interests of employees is one of the purposes of legislating. In addition, labor supervision provides employees with a convenient helpful way after the dispute, which would benefits the relief of labor conflicts, maintaining of social stability and harmony. In the face of the current growing labor dispute cases, it is urgent to give full play to the role of labor supervision system and divert the pressure of handling labor dispute cases.

\section{China's Labor Supervision System's Problems}

The Legislation of Labor Supervision is not Perfect. The overlarge scope of labor supervision matters. According to Article 11 of the Regulations on Labor Security Supervision, the labor supervision includes nine items, such as working out labor contract, drafting rules and regulations, formulating labor standards, etc. It is obvious that China's labor supervision covers an overlarge scope, which would disperse the power of supervision easily and affect the monitoring effectiveness.

The fuzzy boundary of the labor supervision content. China's Labor Dispute Mediation and Arbitration Law stipulates that: "To conclude, perform, change, discharge and terminate the labor contract because of labor relations' confirmation and the dispute about the labor protection, the resignation, the dismissing, the working time, the holiday period, the social insurance, the welfare and the training can all be applied to this Act. " Referring to the labor supervision content above-mentioned, there is overlapped content between labor supervision and labor dispute mediation and arbitration, which will lead to work dislocation in practice, mutual buck-passing responsibility, the low administrative efficiency and the lack of relief of employees' rights timely when damaged.

The Labor Supervision Organizational Structure System does not Work Smoothly. Too much local government intervention in labor supervision. At present, GDP is one of the important criteria for the performance evaluation of local governments. Therefore, many local governments 
aim to promote local economic development by introducing a lot of investment. Most of the enterprises are the local main taxpayer, which labor supervision and related law enforcement department of local government do not pay enough attention to and even sometimes tolerate some of the employer's illegal activities. In one word, labor supervision does not play its due role. Under control of the human and material resources, labor supervision department under the leadership and management of local government is difficult to enforce the law independently while the rights and interests of employees cannot be maintained.

The lack of coordination and cooperation with the relevant departments. One of the characteristics of labor supervision is its comprehensive nature. It is a comprehensive supervision to the employing units, covering all parts of the labor relations and operational links. In practice, the employing units would accept various checks from related units annually, such as the business sector and the health sector. Although these inspections are different from labor supervisions, they all check the employer in certain respects. When labor supervision departments supervising, they often involve the inspection contents of other departments, which often resulting in inspection duplication when coordination and coordination are in shortage. Or the employing unit refuses the labor supervision in the name of being inspected by a special unit. However, the cost of labor supervision is relatively low comparing the business sector's annual inspection that equipped with strong punishing ways like revoking the business license and generally only ordering to correct it and has poor coordination with the industry and commerce, public security and judicial departments. Labor supervision works little [2].

The lag of labor supervision team building. Specialized and high-quality labor supervision team is to ensure the effectiveness of labor supervision. At present, there is a large gap between China's labor supervision team's building and the actual needs. There are two aspects: Firstly, the number of workers in labor supervision team is inadequate, which cannot meet the needs of labor supervision. Secondly, the quality of them is not high, increasing the work of labor supervision. Due to the malpractice of the system, a lot of recruited workers do not possess the professional quality, which not only occupy the job opportunities, but also cannot cope with the increasing labor supervision work. At the same time the job training is not in place, resulting in the gap appeared between the overall quality and the actual needs of the labor supervision team.

The Labor Supervision Law Enforcement Mechanism is Imperfect. The lack role of labor supervision to play in advance of prevention. As mentioned above, labor supervision could prevent the occurrence of disputes. Only by exerting the function of prevention of labor supervision in advance, avoiding the contradiction between employers and employees, resolving labor disputes in time can relieve the pressure in the process of handling labor disputes. However, at present, China's labor supervision is passive that lacks initiative and does not play the function of the prevention of controversy.

The inadequate labor supervision punishment and illegal low cost. In accordance with the Regulations on Labor Security Supervision and the relevant provisions, the labor supervision department may, according to the different circumstances, adopt some administrative penalties like taking warnings of illegal acts in the course of administrative law enforcement, ordering to make corrections on the spot or within a time limit, confiscating the illegal gains, ordering fines, revoking the licenses and banning illegal organizations. However, the law does not give labor supervision departments the power of closing down the employing units, seizure, lien and other administrative coercive measures which in many cases can the labor supervision department not work smoothly, such as the employing unit absconding and destroying the bill books. It is the existed flaws that damage the labor supervision department's credibility. At the same time, the lower amount of fines comparing illegal profits leads to the lower employer's illegal cost, exacerbating the damage to the interests of employees.

The overlarge discretion of labor supervision. In the labor supervision system, labor supervision departments enjoy certain discretion in law enforcement for different cases. For example, Article 30 of Labor Security Supervision Ordinance stipulates: "The labor and social security administrative department shall order correction and impose a fine of not less than 2,000 yuan but not more than 
20,000 yuan with the following acts... ". Although the administrative discretion granted to labor supervision departments can help protect the fairness of cases, it can easily lead to discretion abuses in practice. In addition, the severity of enforcement is not uniform, which damages the prestige of the law.

The lack of necessary supervision and the disconnection of power and responsibility of law enforcement system. Any power should be limited and under its corresponding supervision and control mechanism. In reality, there are some bad acts lack of necessary supervision like the abuse of administrative power in the labor supervision process, the wide range of law enforcement standards, or the improper law enforcement procedures, the lack of the necessary procedures and so on. What is more, the main body of the power and responsibility is not clear, easily damaged the legitimate rights and interests of the private party of the administration [3].

\section{The Experience of International Labor Supervision can be Learned}

To Improve the Labor Supervision Organization System. Most countries have a sound labor supervision organization system and manage it by taking vertical approach. For instance: Norway's labor supervision system consists of the state labor supervision agencies and local municipal labor supervision agencies. The State Labor Supervision Agency in the central is composed of the State Labor Supervision Department and the Regional Labor Supervision Department manages the country's labor supervision work. The municipal labor supervision agencies are in contact with each other following the instructions of the national authority.

To Enhance the Legal Effectiveness of Supervision Enforcement and Execution. In recent years, the international labor supervision organizations began to pay attention to the legal effectiveness of supervision enforcement and execution. Depending on the seriousness of the case, they put forward rectification proposals or even punishment. In accordance with Article 13 of the 1947 Labor Inspection Convention and Article 18 of the 1969 (Agriculture) Labor Inspection Convention, labor inspectors in many countries may take measures such as suspending the production process, even shutting down the plant in the case of destroying employees' health or safety. And more and more countries have focused surveillance on prevention, such as the Viet Nam Labor Supervision Department managing the National Occupational Safety and Health Week in the workplace in order to raise the public awareness and train the labor inspectors.

To Strengthen the Capacity-building of Supervisory Bodies and Labor Inspectors. Most countries are taking measures to strengthen the capacity of labor inspectors to cope with changing workplace hazards. For instance, Australia has identified strategic labor supervision and enforcement as an important component of the national Occupational Safety and Health (OSH) strategy. France adopted in 2005 an occupational health action plan to train in the field of occupational safety and health.

\section{The Improvement of China's Labor Supervision System}

Perfecting Labor Supervision Legislation and Defining the Scope of Labor Supervision. At present, the scope of labor supervision in our country is too wide, which is almost the same as that of labor administration. In particular, when the insufficient inspector number has weakened the strength of supervision and affects the effectiveness of supervision. Therefore, the matter of labor supervision should be decreased and make labor supervision clearer. The matter of supervision should be mainly limited to the factual situation of the labor benchmarks, with the aim of achieving matters relating to the minimum interests of the employees [4]. And the scope of labor supervision should be clearly defined and make a clear division with labor disputes mediation, arbitration, etc. to avoid confusion, improper use and re-use to reduce administrative efficiency and so on.

To Improve the Labor Supervision Organization System. The establishment of a vertical leadership of labor supervision system from the central to the local. China's current labor supervision system adopts the territorial management pattern. Too much interventions of labor supervision from the local government is not conducive to the role of labor supervision system. In 
combination with China's national conditions, we should establish a centralized labor supervision system with vertical leadership to ensure the effectiveness of labor supervision. Firstly, the labor supervision agencies of the labor administration departments, health administrative departments and other relevant departments should be separated to establish an independent labor supervision organizations to exert the labor supervision function uniformly. Secondly, the establishment of a labor supervision system's vertical leadership from the central to the local is required while establishing the labor supervision departments at the central level to monitor the work in the local administrative divisions in accordance with the establishment of provincial, municipal and county labor supervision departments. Then the higher authorities have supervision and management on the lower one directly. Thirdly, it is necessary to clarify the relationship between the labor supervision agencies and labor dispute mediation and arbitration institutions, avoiding mutual interference, shirking responsibility and effectively protecting the rights and interests of employees.

The establishment of the statutory supervision system with the administrative and judicial coordination and operation. In view of the harsh labor supervision situation, the urgency of strengthening the coordination and cooperation between the labor supervision and administrative and judiciary departments is needed to play the overall effectiveness of law enforcement. We can refer to the joint prevention and control system in environmental legal work. In other words, labor supervision departments will hold joint meetings with industry and commerce, public security and judicial departments regularly to cooperate with each other, share information and carry out joint law enforcement. And the final aim of these measures is to strengthen the assistance and support to labor supervision. For example, the business sector can take measures not through its annual inspection or revocation of business licenses to punish the employing units that did not perform the decisions made by the labor supervision departments; The judiciary can provide more convenient channels when employees whose legitimate rights and interests damaged seek relief; The public security department can take penalties to the corresponding illegal employment behavior and so on.

To strengthen the construction of the labor supervision team. A high level of labor supervision team can ensure the effectiveness of labor supervision. First, increasing the number of labor inspectors as many as possible ensures the reasonable ratio of the number of the labor inspectors and that of employers in the international provisions dynamically. At the same time, adopt the approach that combines the part-time and full-time staff. Second, strengthen job training to improve the professional quality of labor inspectors. The existing labor inspectors can carry out professional training on a regular basis to strengthen their professional quality; For the new labor inspectors, recruitment should be strict for the work. The ways of recruitment can be professional examinations, interviews and other means.

To Improve the Labor Supervision Law Enforcement Mechanism. The establishment of labor supervision early warning mechanism to play a preventive function of controversy. In addition to solving labor disputes, labor supervisions should play its role in the prevention of labor disputes to build a harmonious and stable labor relations. The labor supervision department may carry out supervision work by supervising and inspecting the written materials submitted by the employing units and accepting reports and complaints which can timely discover and resolve the disputes. In the meanwhile, we can give full play to the supervisory function of labor unions and establish channels for good communication with labor unions. Through that we can strengthen supervision over employing units in the way labor unions promptly handle illegal acts. With the progress of science and technology, labor supervision departments can also introduce technical means to implement labor supervision such as real-time transmission through the Internet, etc. By this way we can strengthen the wages payment, social insurance payment and so on.

To increase penalties and enhance the power of labor supervision law enforcement. At present, the punishment of labor supervision in our country is low and the law enforcement power focus on administrative punishment, which is not conducive to the role of labor supervision. Therefore, it is urgent to increase the law enforcement power of labor supervision department. First of all, the right of administrative mediation can be given to the labor supervision departments that can organize the parties to mediation, resolving contradictions which is more conducive to social stability; Secondly, 
the labor supervision departments should be equipped with the necessary preservation measures of the property and evidence in order to smooth the work; Thirdly, the administrative coercive measures of labor supervision shall be added to strengthen the authority through closing down the employing units, seizure, ordering to suspend production or revoking business license and so on to increase penalties and protect the rights and interests of employees.

To refine the standard of the discretion. The Labor Security Supervision Regulations provides a principle framework for the labor supervision departments' work, and the local supervisory departments shall enjoy discretion within a certain scope according to the specific local conditions and the specific circumstances of the cases. In order to avoid excessive discretion, the standard of discretion should be refined and the law enforcement behavior of supervisors should be regulated. Above all, the discretion should be exercised rationally and the abuse of power should be prevented to free the damage to the social order.

Strict labor supervision responsibility system. A good monitoring mechanism is more beneficial to ensuring the effectiveness of labor supervision. It is necessary to establish an internal supervision mechanism for labor supervision while strengthening the supervision of the masses and the public media so as to prevent power abuse. At the same time, the correct identification of labor inspectors' administrative and criminal responsibility is required to identify the main responsibility's owner to increase the sanctions against the illegal behaviors.

\section{Conclusion}

To sum up, it is imperative to establish a perfect and effective labor supervision system in view of the current increasing and complex labor dispute cases. Although China's labor supervision system has some problems in legislating, organizational structure system and law enforcement mechanism, labor supervision will play a greater role in easing labor relations and maintaining social stability through continuous research and improvement.

\section{Reference}

[1] J.Lin. Labor Law and Social Security Law [M]. Beijing: China Renmin University Press, 2016: 244.

[2] R.Wang, Y.Y.Zhao and R.Du. Analysis of labor security monitoring problems and countermeasures [J]. Human Resource Management, 2014, (08).

[3] X.H.Cao, W.Xu. Research on the Labor Supervision under the Construction of Government Ruled by Law [J]. Journal of Shandong University of Technology, 2015, (9).

[4] Q.X.Wang. Labor Law [M]. Beijing: Law Press, 2008: 471-472. 